UDC 378.091:005.6]:378.4

O. Aleksandrova ${ }^{1}$, Dr. Sc. (Philos.), Prof., orcid.org/0000-0003-0030-1367,

I. Hroznyi ${ }^{2}$, Dr. Sc. (Econ.), Prof., orcid.org/0000-0001-8083-3050,

N. Vinnikova ${ }^{1}$, Dr. Sc. (Philol.), Assoc. Prof., orcid.org/0000-0002-5162-4150,

N. Chuvasova ${ }^{3}$, Dr. Sc. (Ped.),

orcid.org/0000-0001-7636-6277
DOI: $10.29202 /$ nvngu/2019-2/18

1 - Borys Grinchenko Kyiv University, Kyiv, Ukraine, e-mail: olena.aleksandrova@yahoo.com; n.vinnikova@kubg.edu.ua 2 - European University, Kyiv, Ukraine, e-mail: grozny_ igor@ukr.net

3 - Kryvyi Rih State Pedagogical University, Kryvyi Rih, Ukraine, e-mail: k_chemistry@kdpu.edu.ua

\title{
CONTROL OF THE QUALITY ASSURANCE SYSTEM AT THE MODERN UKRAINIAN UNIVERSITY
}

Purpose. Developing an internal assessment and quality assurance system at Ukrainian universities to increase their competitiveness in the context of globalization and internationalization of higher education.

Methodology. The use of systemic, structural-functional, institutional approaches provides an opportunity to study international experience in assessing the quality of higher education and find ways to implement it in Ukrainian realities. The use of methods of analysis, synthesis, generalization, comparison, expert assessment allows the authors to develop a system of internal audit at universities. The use of a qualimetric approach allowed the authors to propose an algorithm for calculating the quality of higher education at universities based on a set of quantitative indicators.

Findings. The analysis of international experience in ensuring the competitiveness of higher education made it possible to identify the criteria by which the quality of education is assessed, to develop an algorithm for conducting an internal assessment of the quality of higher education and to determine the mechanism for its control at Ukrainian universities. Education quality assessment at a university consists of an analysis of basic management processes, complementary processes and improvement processes. The level of functioning of these processes affects the quality of higher education, which, in turn, makes it possible to substantiate the factors of further increasing of the productivity of the university in the provision of educational services.

Originality. A strategy has been developed for creating a system of internal quality assurance in higher education at Ukrainian universities. It can be realized through the identification of advantages and disadvantages, opportunities and threats of conducting an internal audit of the quality of higher education, as well as by analyzing international experience in ensuring the competitiveness of higher education, which is summarized in the relevant quality standards. An algorithm has been developed for assessing the quality of higher education at Ukrainian universities and the specificity of educational activity management has been determined on the basis of a qualitative assessment of the quality (utility) of educational services.

Practical value. The results of the study can be used to implement and/or improve the mechanism of internal audit of the system of education quality at universities.

Keywords: education quality assessment, university, competitiveness, management, control

Introduction. In modern conditions, education has become one of the key factors in improving a country's competitiveness. Quality improvement is a global strategy of modern higher education development.

In Ukraine, according to the new Law on Education and the Law on Higher Education, in the national system of higher education there should be two education quality assurance systems: external and internal. As for the external system, everything is more or less specified, because there are certain regulatory requirements: educational standards, licensing and accreditation of educational activities, state certification, rating assessment, and others. Nowadays, namely the external education quality assurance system is in the focus of attention of academic community [1]. However, in the light of university autonomy, the internal education quality assurance system is equally important. This allows the university to respond quickly and flexibly to the demands of the labor market and, in accordance with them, train

(C) Aleksandrova O., Hroznyi I., Vinnikova N., Chuvasova N., 2019 competitive specialists. Unfortunately, this system remains underestimated in the Ukrainian society. This is evident from the data of the sociological survey of 2017: out of 124 universities of different regions of Ukraine (96\% of state ownership), only $47 \%$ have special units for education quality management, whose activities, for objective reasons, require further improvement and approximation to contemporary European practice [2]. Thus, establishment of the internal education quality assurance system is an urgent present-day need.

Analysis of the recent research and publications. Education quality in the context of modern needs, problems of its assessment are examined in the works by the following scientists: S. Arkhypova, T. Lukina, O. Liashenko, O. Lokshyna, V.Safonova, O. Subbeto, M. Frolova, and others.

Analysis of the criteria for education quality is present in the works by Yu. Konarzhevskyi, L. Redko, N. Zadorozhniuk, T. Khliebnikova, H. Yelnykova, V. Bakhrushyn, and others.

In the context of assessment and determination of the conditions to assure the education quality in Western 
universities, attention should be paid to the works of the following scientists, such as Manfred Herzer, Uwe Schmidt, Jane Knight, Axel Aerden, Mark Frederiks, Lukas Bischof, Carita Blomqvist, Lucien Bollaert, Howard Davies, Peter Williams, Nora Skaburskiene, Giedrius Viliunas, Linda Messas, Martin Prchal, and others.

Unsolved aspects of the problem. At the same time, despite the large number of the works devoted to the education quality, the problem of specificity of assessment and opportunities for the higher education quality assurance remains unsolved in the light of modern Ukrainian realities and the search for the ways of applying world experience is essential, especially when this includes the internal quality assurance.

Objectives of the article. Hence, the core objectives of the research are the following: 1) analysis of the process of establishment of the internal higher education quality assurance system at the Ukrainian universities; 2) determination of the strengths and weaknesses, opportunities and threats of providing the internal quality assurance audit in higher education; 3) analysis of the international experience in assuring higher education competitiveness that is generalized in the relevant quality standards; 4) development of the algorithm for carrying out higher education quality assessment at the Ukrainian universities, based on the international experience, and taking into account the current Ukrainian specificity of the academic environment; 5) determination of the criteria for carrying out higher education quality assessment.

Methods. The achievement of the objectives will assure the application of the system, structural and functional, and institutional approaches. The application of the methods of analysis, synthesis, generalization, comparison, and expert evaluation will allow establishing the internal audit system at the universities. With the help of the qualitative approach, the problem of the higher education quality will be solved.

Presentation of the main research. International experience in education quality assurance is based on two basic principles: the principle of the autonomy of higher education institutions, which correlates with the principle of responsibility towards consumers of educational services - students, employers, and society as a whole for qualitative specialist training.

The education quality monitoring and assessment can take place at different levels (international, national, regional, local/internal (at the level of University, faculty, training program), but, in general, the expert environment pays attention to: internal quality assurance in higher education institutions, external higher education quality assurance, quality assurance in the activities of agencies for external education quality assurance. Specific nature of assessment depends on historically established educational management systems - centralized (tradition of the countries of Europe and the CIS) - assessment is mainly carried out by the State educational authorities, and decentralized (tradition of the USA) assessment is mainly carried out by the educational institutions themselves in the form of internal analysis, aimed at increasing their competitive strength.
With regard to the modern Ukrainian realities, as already pointed out, the attention of the academic community is focused on the external education quality assurance - the activities of the MES and NAHEQA. The authors of the research draw attention to the specifics of the establishment of the internal quality assurance system in higher education institutions, as well as the conditions and possibilities for its control.

A number of factors impede the process of establishment of the internal higher education quality assurance system at the Ukrainian universities. The most influential factors among them are the following: lack of resources; lack of trained experts in this field; lack of motivation of the part of staff; low level of school graduates; lack of experience in functioning of universities in conditions of autonomy; national traditions of management; inability to work without state standards and other normative documents; self-maintenance of some domestic universities; dominance of formal methods among the tools for assessing the education quality and learning. These factors need to be considered in a more comprehensive manner with access to the relevant recommendations.

To establish an effective system of internal education quality assurance, it is necessary to involve external stakeholders and focus on their needs (employers, practitioners, scientists, university entrants, parents) [3]. Meanwhile, the Ukrainian universities have a preference for internal stakeholders (the management, lecturers, and students). The main reason for this is to prevent the leak of undesirable information, furthermore, despite the proclaimed student-centrism; the university management does not always take into account students' needs and opinions about the quality of provided educational services.

The functioning of the internal education quality assurance system is influenced by the national management traditions, the basis of which is the legacy of the Soviet bureaucracy. Thus, the focus of the universities mostly on the new regulatory documents of the MES is observed or the future focus on the new directives of NAHEQA (National Agency for Higher Education Quality Assurance) is projected.

To this should be added that in the traditions of national educational thought the emphasis is on the cultural and civilizational self-identification of university education. It determines corresponding specificity of the educational process quality assurance: special account for the socio-humanitarian profile, national characteristics, and traditions in the content of some curricula; support for students' active role in determination of the trajectory of personal development; paying attention to life-long and non-formal education.

As the practice of education quality assessment at the modern universities, not to mention monitoring, is still in the development stage, so assessment tools are not always applied effectively, and there are no experts in this field yet. The Ukrainian universities' imperative is the selection of internal auditors, who are well aware of the normative documents regulating activities of educational institutions, theory of management, manage- 
ment, fundamentals of economics, pedagogy, pedagogical and social psychology, management psychology and have authority among colleagues. The need is to improve the auditors' competence continuously through methodological workshops, as well as exchange of experience with other universities. Unfortunately, this opportunity is implemented to a very limited extent, since universities are reluctant to invite colleagues from foreign universities and often do not want to share confidential information, which includes the content of educational programs and the experience of their implementation. Besides, deputy principals, deans and heads of subdepartments often act as such auditors. Based on their own management experience, they can more or less qualitatively carry out the audit of the work of other units on the processes that are familiar to them, namely, educational, scientific, social and humanitarian. However, they do not have professional training for carrying out the audit of infrastructure management and working environment, document management, financial reporting, legal documentation audit, risk management, and others. The problem becomes more complex due to the lack of research and methodological literature on the audit in educational institutions. Scientific study of individual researchers does not give ready answers regarding preparation of the program of internal audits, determination of indicators and criteria for the effectiveness and efficiency of the process, compilation of questionnaires, documentation, and others. This problem is compounded by stereotyped thinking of education workers, bias towards the auditors, and, often, by lack of critical attitude to work in their own structural units of the management team at the universities. Thus, each university develops its own experience.

There is also the tendency to compare the Ukrainian universities with the best domestic higher education institutions, although it would be more rational to compare domestic universities with European ones and to focus on the best European and world systems of education quality assurance; otherwise, self-maintenance of the universities takes place [4].

In this case, the reaction of the Ukrainian universities to the requirements and demands of the labor market would be more effective. It means not only the opening of new educational programs, which is often done in domestic universities, but also the closure of noncompetitive old ones. At best, what is done with the latter is that they are provided with external modifications. In addition, a distortion of the motivational component in these modifications takes place, namely, the emphasis is given to the maintaining workload of relevant subdepartments, rather than to meeting the needs of students and other stakeholders.

Formal methods, such as work programs content assessment and quality audit of teaching methodology, dominate among the tools used to determine the quality of teaching of certain disciplines. Internal assessment tools, such as students' and teachers' views, are less applied, as well as external assessment tools, such as the employer opinion survey, the external experts review, which are applied to a lesser extent. Furthermore, this should include not only the quality of teaching and the level of students' knowledge; this should be the matter of assessment of the effectiveness of university management, establishment of new modern educational programs for training specialists for the labor market, assurance of academic mobility, assessment of the level of internationalization of education, and others.

However, the strengths of the internal analysis and control of the education quality assurance are obvious. As the process of internal assessment is initiated by the management of universities, then, firstly, there is certain interest of the management in the objective outcomes to promote the effective quality management of the core and supporting university processes; secondly, researching the state of affairs, the auditor suggests the heads of the relevant structural units joint determination of the ways to solve the problems that are most adequate for this unit, avoiding the dictation of the algorithm of actions in problem situations; thirdly, cooperative relations of both parties are established, since the objective is not to punish the staff, but to determine the reasons for the deterioration in the quality of educational services provision; fourthly, benchmarking may be the outcome of the internal audit (transferring the best experience of some units to the others).

Strengths and weaknesses, opportunities and threats in carrying out internal assessment of higher education quality assurance can be seen with the help of SWOT analysis (Table 1).

With a view of establishment of the internal quality assessment system of the Ukrainian higher education, it is necessary to turn to the experience of activity of the International Network for Quality Assurance Agencies in Higher Education (INQAAHE) and European Association for Quality Assurance in Higher Education (ENQA). All organizations as members of INQAAHE in varying degrees are concentrated on quality standards.

The comparative analysis of three internationally recognized quality standards, as well as quality standards for some member organizations of INQAAHE, and Asian quality standards for higher education (for example, in Japan) are presented in Table 2.

The analysis of the data presented in Table 2, enables the author to conclude that the key factors that assure education quality, and, at the same time, are criteria for achieving competitive strengths include the following ones:

1. Students (the number of enrolled students) and assessment of their achievements: the quality and success of learning; scientific work; student mobility.

2. Staff potential: number of scientific publications per worker; citation index; inventions/patents/copyrights of the staff; mobility of the teaching staff; participation in the implementation of international projects, research studies and programs; average age.

3. Learning: learning courses and educational programs, availability of curricula, measurements of graduates' outcomes.

4. Financial planning and resources: material and technical; information; social and domestic.

5. Management: assessment of the quality of managerial decisions; assessment of the university strategy. 
The SWOT analysis of internal assessment of higher education quality assurance

\begin{tabular}{|c|c|}
\hline $\begin{array}{l}\text { Strengths } \\
\text { - interest of the university management in objective outcomes; } \\
\text { - establishment of cooperative relations of all stakeholders } \\
\text { (those who are audited, university management and experts) } \\
\text { and their joint participation in managerial decisions making; } \\
\text { - promotion of the effective quality management of the } \\
\text { core and supporting processes of the University; } \\
\text { - benchmarking as the outcome of the internal audit }\end{array}$ & $\begin{array}{l}\text { Weaknesses } \\
\text { - limited resources for services provision; } \\
\text { - lack of clarity of internal processes of standardization and } \\
\text { communication; } \\
\text { - insufficient opportunities for staff motivation; } \\
\text { - insufficiently established external communication with } \\
\text { stakeholders }\end{array}$ \\
\hline $\begin{array}{l}\text { Opportunities } \\
\text { - assurance of consistency and continuity of the internal } \\
\text { quality assessment process based on reflection and } \\
\text { self-reflection; } \\
\text { - carrying out of the audit by specially trained experts; } \\
\text { - development of the methodology for providing services } \\
\text { that meet the international standards; } \\
\text { - development of the quality culture; } \\
\text { - development of the university competencies in the field of } \\
\text { higher education quality recognition, internationalization } \\
\text { and assurance }\end{array}$ & $\begin{array}{l}\text { Threats } \\
\text { - changes in the legal environment (new Laws "On } \\
\text { Education", "On Higher Education", NAHEQA reloading); } \\
\text { - lack of experience of university functioning in } \\
\text { conditions of autonomy; } \\
\text { - limited resources (human, infrastructural, uncertainty of } \\
\text { funding sources to carry out functions of internal audit); } \\
\text { - lack of experience, limited internship opportunities for } \\
\text { Ukrainian specialists in international organizations in education } \\
\text { quality assessment }\end{array}$ \\
\hline
\end{tabular}

6. Internal (students, lecturers, associate staff) and external (graduates, enterprises and institutions, independent experts, international scientific community) communication.

The analysis of international experience in higher education competitiveness assurance, generalized in the relevant quality standards, allows us to determine the criteria for education quality assessment and to develop the algorithm for carrying out the higher education quality assessment at the Ukrainian universities.

The quality assurance assessment at the university consists in analyzing the core management processes, complementary processes, and improvement processes. Based on the level of these processes functioning, the quality of higher education is assessed and the factors of further University productivity improvement in providing educational services are substantiated.

I. The core processes are analyzed according to these indicators:

1. Planning activities and determining the university budget:

1.1. University development strategy that is how the organization plans to implement its major activities:

- missions and visions;

- objectives;

- priorities;

- leadership that is how the top management leads the organization and how the organization positions itself in society from the point of view of social responsibility.

2. Organization of:

2.1. Educational process:

- normative-methodical support;

- road map (assurance strategy) of the quality of the educational process;

- educational and educational-scientific programs and their compliance with the standards and demands of the labor market.

2.2. Scientific activity:
- level of internationalization of higher education and science;

- management of scientific researches, projects and programs;

- printing activity of scientific and pedagogical staff and students.

\section{Control:}

3.1. Accounting and financial reporting.

3.2. Legal audit.

II. The complementary processes are analyzed according to these indicators:

1. Efficiency of sharing functional responsibilities between units and staff.

2. Internal cooperation assurance.

3. Documentation control.

4. HR audit:

4.1. Staff management (assessment of scientific and pedagogical staff and construction of the trajectory for its professional development).

4.2. Dynamics of student enrollment.

4.3. Graduates (job placement indicators).

5. Infrastructure management and security.

6. Partnership with stakeholders.

7. Students and staff support service management.

III. Improvement processes:

1. Providing feedback from stakeholders.

2. Internal audit self-assessment.

3. Patch management and preventive actions.

In general, the analysis of these processes covers five main aspects of the internal audit: the audit of the achievement of the objectives of training specialists; the audit of the goals and objectives of the higher education institutions for the needs of socio-economic development of the country and its individual regions; the audit of the effectiveness of providing professorial teaching staff and educational resources; the audit of the effectiveness of the higher education quality assurance system; the audit of students' and employers' satisfaction. 


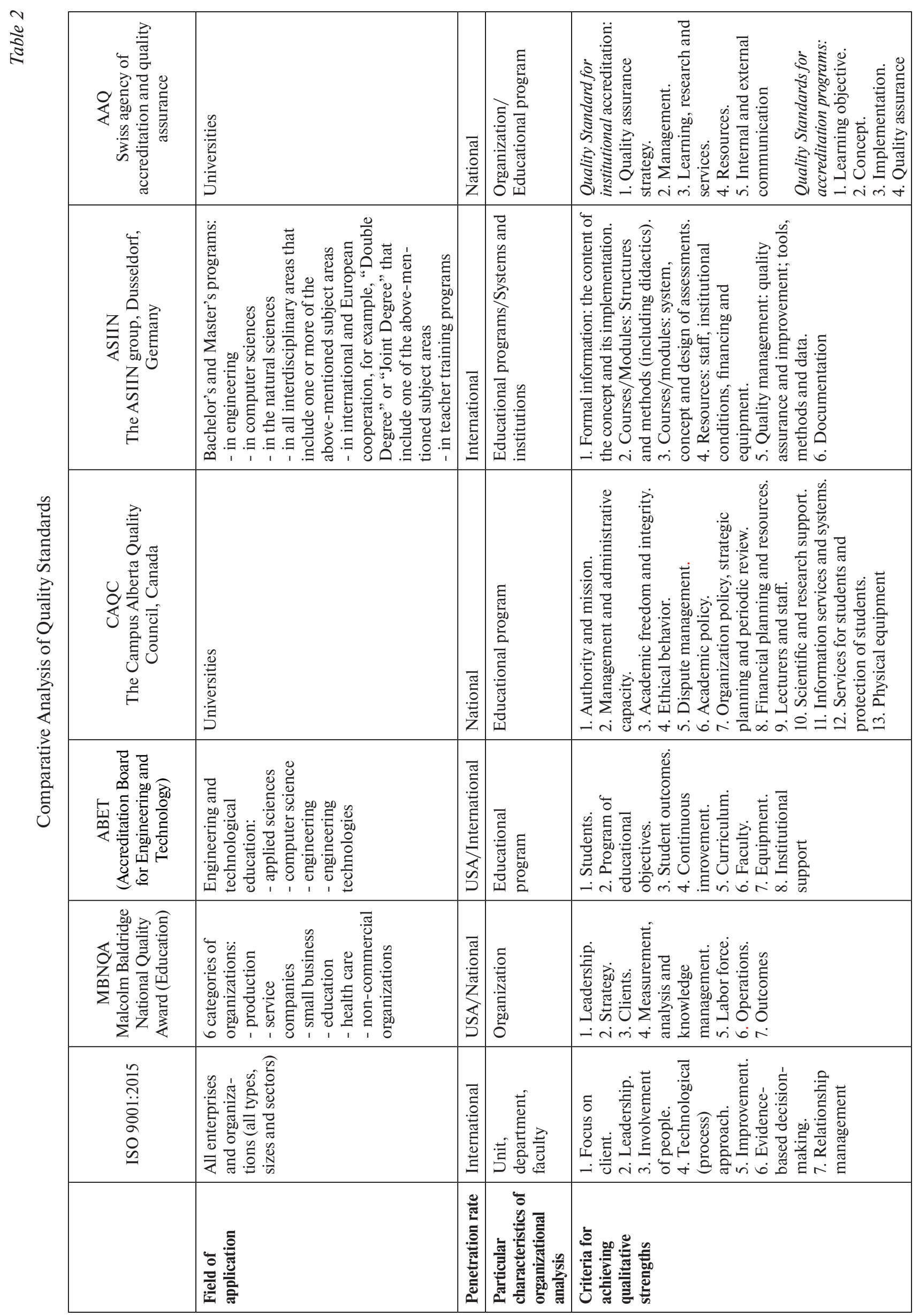




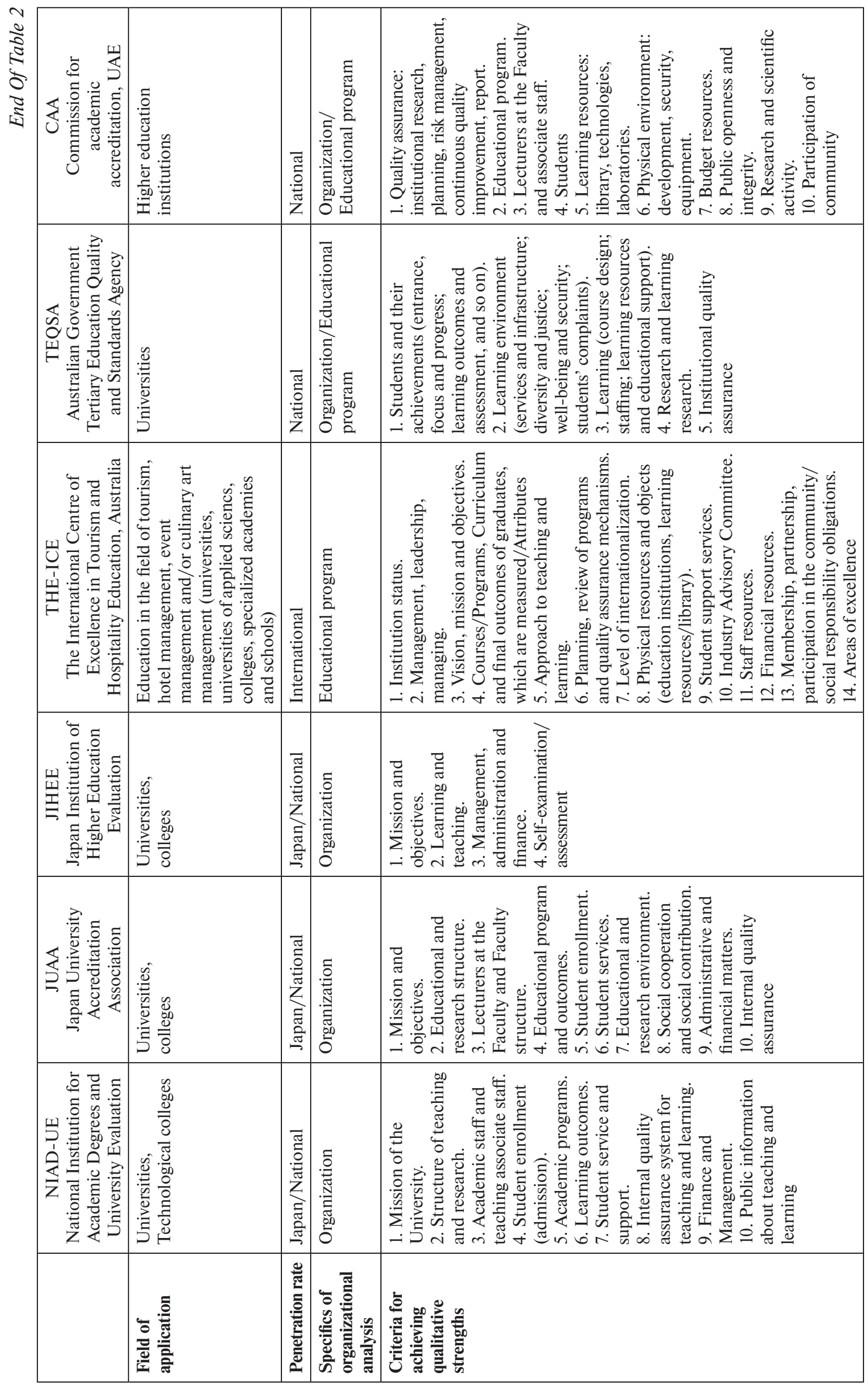


The described system of higher education quality audit is presented in Table 3.

The problem on how it is possible to assess the higher education quality in quantitative terms remains unsolved. There are several suggestions to solve this problem.

For example, higher education quality can be assessed on the basis of the integral indicator, which is built as a set of individual indicators. In the simplest case, according to V. Bakhrushin, such an integral indicator is a weighted sum of individual indicators

$$
I=\alpha 1 \mathrm{I} 1+\alpha 2 \mathrm{I} 2+\ldots+\alpha n \mathrm{I} n,
$$

where $\alpha i$ is weighting factors that are determined by diagnostic expertise and should satisfy the requirement: $\alpha 1+\alpha 2+\ldots+\alpha n=1$. The very method is used to calculate rankings to determine top universities - THE, or Times, ARWU, QS, Webometrics, TOP-200 Ukrainian universities and others.

The opportunity to occupy the leading positions in these rankings is the universities' stimuli for education quality improvement and gaining of the appropriate competitive strengths [5].

The second example can be found in the works by Sh. Askerov. According to the scientist, the new criterion of human development is in the focus of attention of modern countries [6]. The ratio of the carried out part of work (physical or intellectual) $(a)$ to not carried out one $(h)$ was taken as a criterion, since the sum of performed $(a)$ and unperformed parts $(h)$ of work is equal to one, we can write

$$
a+h=1 .
$$

The new criterion is called a qualitative factor $(K)$ and is determined using the following formula

$$
K=a / h=a / 1-a .
$$

Factor $K$ demonstrates the extent to which the part of the work performed $(a)$ therefore exceeds the part of the work unperformed $(1-a)$. This criterion is an alternative to productive (in percent) activity. Depending on

Table 3

Higher Education Quality Audit

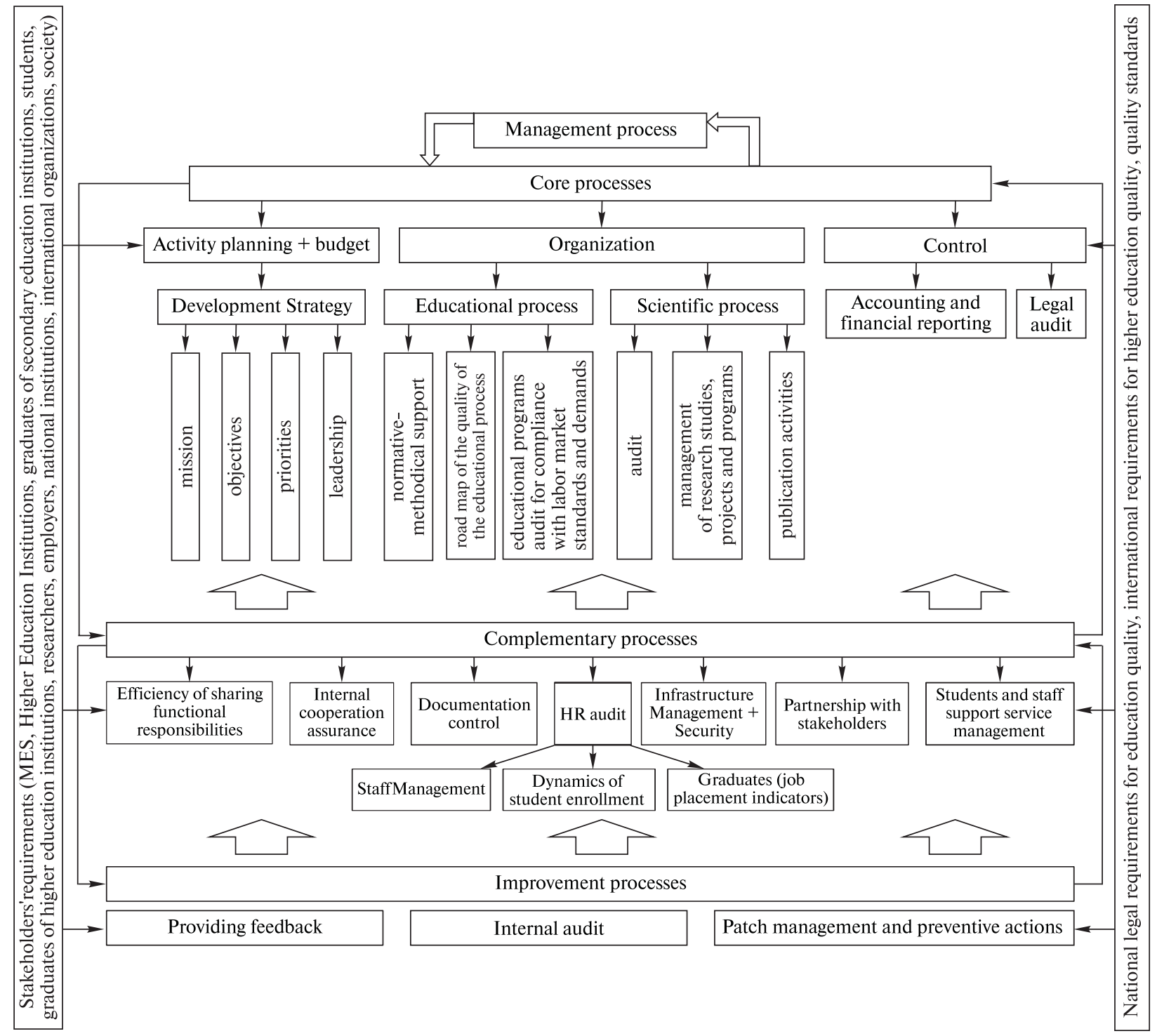


the field of application, $K$ has different meanings. For example, in the knowledge assessment $K$ points to the ratio of what we know to what we do not know [6].

The third example can be built based on the qualimetric approach [7, 8]. In order to use the qualimetric approach to higher education quality assessment, it is necessary to establish the assessment indicators system to determine the scale or scales on which these indicators will be assessed, as well as to develop the criteria, which enable the interpretation of the outputs obtained. Obviously, some properties and indicators can be assessed using formalized methods, while others can be assessed only using heuristic methods.

Qualimetric quality assessment, in essence, is only the basis and the initial stage of the complex process of quality management in higher education. Without knowing the level of properties and qualities of the analyzed processes, it is impossible to make science-based managerial decisions and exert subsequently the appropriate preventive or corrective impact on the process with an objective of changing the quality.

To establish the best quality of the level of activity of the educational and research institution (ERI), it is necessary to find balance between motivation and competence of a scientific and educational worker in order to increase his/her usefulness for the ERI (Table 4).

The authors of the research suggest the following vision. The degree of quality of the ERI activity is formed on the basis of a set of high-quality professional activities of workers, who form the corresponding ranking

$$
U_{i j}=\left(C P_{i j}+P A_{i j}+C P_{i j}+C C O_{i j}\right) M M_{i j},
$$

where $U_{i j}$ is the usefulness of the i number of worker of the $j$ number of the ERI unit, points; $C P_{i j}$ is competence, points; $P A_{i j}$ is professional activity, points; $C P_{i j}$ is creativity, points; $C C O_{\mathrm{ij}}$ is competence compliance with the objective of the ERI, points; $M M_{i j}$ stands for motivational measures.

Conclusions. Specificity and trends in the development of modern education require universities to play the leading role in human capital formation, which is possible through their own competitiveness improvement. One of the factors of competitiveness improvement is the educational services quality assessment and, accordingly, conditions and opportunities creation for the establishment of the education quality assurance system. The latter consists of many components analyzed by the authors of the article, the core ones of which are the internal assessment and the control of the education quality assurance.

The analysis of the international experience in higher education competitiveness assurance, has allowed determining the criteria for the education quality assessment and developing the algorithm for carrying out higher education quality assessment at the Ukrainian universities. The quality assurance assessment at the university consists of the analysis of the core management processes, complementary processes, and improvement processes. The level of functioning of these
Table 4

Educational Activity Management on the bases of Qualimetric Quality Assessment (The Improvement of Usefulness)

\begin{tabular}{|c|c|c|c|c|c|c|c|}
\hline 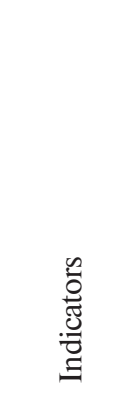 & 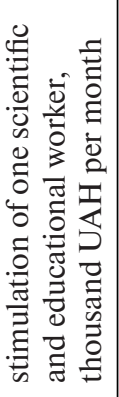 & 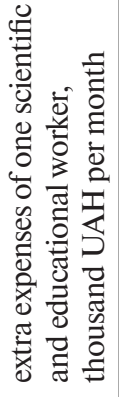 & 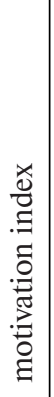 & 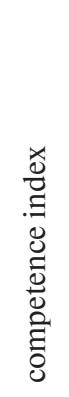 & 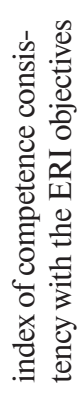 & 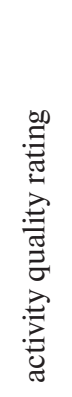 & 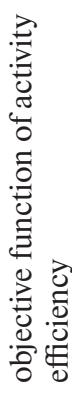 \\
\hline \multicolumn{8}{|c|}{ Educational and Research Institution A } \\
\hline $\begin{array}{l}\text { Before } \\
\text { measures }\end{array}$ & 0.95 & 0.5 & & 0.64 & 0.6 & 0.94 & 0.59 \\
\hline After & 1.64 & 0.5 & & 1.0 & 1.0 & 1.0 & 1.0 \\
\hline \multicolumn{8}{|c|}{ Educational and Research Institution B } \\
\hline $\begin{array}{l}\text { Before } \\
\text { measures }\end{array}$ & 0.95 & 0.5 & & 0.52 & 0.6 & 0.85 & 0.77 \\
\hline After & 1.49 & 0.5 & & 1.0 & 1.0 & 1.0 & 1.0 \\
\hline \multicolumn{8}{|c|}{ Educational and Research Institution C } \\
\hline $\begin{array}{l}\text { Before } \\
\text { measures }\end{array}$ & 0.95 & 0.5 & & 0.55 & 0.5 & 0.79 & 0.4 \\
\hline After & 1.63 & 0.5 & & 1.0 & 1.0 & 1.0 & 1.0 \\
\hline \multicolumn{8}{|c|}{ Educational and Research Institution D } \\
\hline $\begin{array}{l}\text { Before } \\
\text { measures }\end{array}$ & 0.95 & 0.5 & & 0.6 & 0.5 & 0.44 & 0.41 \\
\hline After & 1.73 & 0.5 & & 1.0 & 1.0 & 1.0 & 1.0 \\
\hline
\end{tabular}

processes affects the higher education quality, which in turn allows us to justify the factors of the further university productivity improvement in the provision of educational services.

Recommendations for further research. The need for university functioning in conditions of autonomy consists in establishment of the special unit for managing the quality of education. The urgent need is also development of the quality culture, with the academic community awareness of the quality priority, which should be reflected in the statute of the university, its strategy, mission, objectives, and action plans.

Considerable success has been achieved by using the internal audit in complementarity with the application of external quality assessment tools such as accreditation by external independent agencies, and benchmarking.

Prospects for further research:

1. Monitoring of the internal and external factors that determine education quality at the modern Ukrainian universities.

2. Research on the conditions and opportunities of the quality culture development at the Ukrainian universities.

3. Development of the methodology for the analysis of the quality of educational programs. 


\section{References.}

1. Rudenko, S., Sapeńko, R., Bazaluk, O. and Tytarenko, V., 2018. Management Features of International Educational Projects between Universities of Poland and Ukraine. Naukovyi Visnyk Natsionalnoho Hirnychoho Universytetu, 2, pp. 142-147. DOI: 10.29202/nvngu/ 2018-2/21.

2. Finikova, T. V. and Tereshchuk, V.I., eds., 2018. Implementation of local quality management systems in Ukrainian universities: Analytical report. Kyiv: Takson [pdf]. Available at: <http://www.edupolicy.org.ua/dx/ assets/images/Analit18ua_08-5mm.pdf $>$ [Accessed 24 May 2018].

3. Aleksandrova, O., Batchenko, L., Dielini, M. and Lavryk, U., 2018. Specifics of Managing Competitiveness of Present-day University on Principles of Social Responsibility. Naukovyi Visnyk Natsionalnoho Hirnychoho Universytetu, 4, pp. 157-165. DOI: 10.29202/ nvngu/2018-4/21.

4. Bazaluk, O., Svyrydenko, D. and Terepyshchyi, S., 2017. Structural-Functional Models of Integration and Reintegration of Ukrainian Educational Landscape. Naukovyi Visnyk Natsionalnoho Hirnychoho Universytetu, 5, pp. 163-168.

5. Bakhrushyn, V., 2013. What is the quality of higher education and how is it measured? [online]. Available at: $<$ http://education-ua.org/ru/articles/100-shcho-takeyakist-vishchoji-osviti-i-yak-jiji-vimiryuyut $>$ [Accessed 17 November 2017].

6. Askerov, Sh., 2018. The Dependence of Human Development on the Degree of Public Interest. Philosophy Study, 8(6), pp. 263-268. DOI: 10.17265/2159$5313 / 2018.06 .002$.

7. Grozny, I. S., 2015. Qualitative approach to monitoring of business processes of industrial enterprises. Ekonomika i upravlinnya, 1(65), pp. 36-41.

8. Khamel, Khaldi, 2017. Quantitative, Qualitative or Mixed Research: Which Paradigm to Use? Journal of Educational and Social Research, 7(2), pp. 15-24. DOI: 10.5901/jesr.2017.v7n2p15.

9. Legislation of Ukraine, 2013. National Strategy for the Development of Education in Ukraine until 2021 (approved by the Decree of the President of Ukraine dated June 25, 2013, No. 344/2013 [online]. Available at: <http://zakon4.rada.gov.ua/laws/show/344/2013> [Accessed 25 January 2018].

\section{Контроль системи забезпечення якості освіти в сучасному українському університеті}

\section{О. С. Александрова ${ }^{1}$, І. С. Грозний ${ }^{2}$, Н. М. Віннікова Н. О. Чувасова ${ }^{3}$}

1 - Київський університет імені Бориса Грінченка, м. Київ, Україна, e-mail: olena.aleksandrova@yahoo.com; n.vinnikova@kubg.edu.ua

2 - Європейський університет, м. Київ, Україна, e-mail: grozny_igor@ukr.net

3 - Криворізький державний педагогічний університет, м. Кривий Ріг, Україна, e-mail: k_chemistry@kdpu. edu.ua
Мета. Розробка системи внутрішньої оцінки й забезпечення якості освіти в українських університетах задля підвищення їх конкурентоспроможності в умовах глобалізації та інтернаціоналізації вищої освіти.

Методика. Використання системного, структурно-функціонального, інституційного підходів дає можливість вивчити міжнародний досвід оцінки якості вищої освіти та знайти шляхи його імплементації в українських реаліях. Застосування методів аналізу, синтезу, узагальнення, порівняння, експертної оцінки дозволяє розробити систему проведення внутрішнього аудиту в університетах. Використання кваліметричного підходу дозволило запропонувати алгоритм розрахунку якості вищої освіти в університетах на основі сукупності кількісних показників.

Результати. Аналіз міжнародного досвіду забезпечення конкурентоздатності вищої освіти дозволив виділити критерії, за якими оцінюється якість освіти, розробити алгоритм проведення внутрішньої оцінки якості вищої освіти та визначити механізм іiі контролю в українських університетах. Оцінка якості освіти в університеті складається 3 аналізу основних процесів управління, взаємодоповнюючих процесів і процесів удосконалення. Рівень функціонування цих процесів впливає на якість вищої освіти, що, у свою чергу, дозволяє обгрунтувати фактори подальшого підвищення продуктивності роботи університету в наданні освітніх послуг.

Наукова новизна. Розроблена стратегія створення системи внутрішнього забезпечення якості вищої освіти в українських університетах. Їі можна втілити через визначення переваг і недоліків, можливостей і загроз проведення внутрішнього аудиту забезпечення якості вищої освіти та за допомогою аналізу міжнародного досвіду забезпечення конкурентоздатності вищої освіти, що узагальнюється у відповідних стандартах якості. Розроблено алгоритм проведення оцінки якості вищої освіти в українських університетах та визначена специфіка управління освітньою діяльністю на основі кваліметричної оцінки якості (підвищення корисності) надання освітніх послуг.

Практична значимість. Результати дослідження можуть бути використані для реалізації та/або вдосконалення механізму внутрішнього аудиту системи забезпечення якості освіти в університеTax.

Ключові слова: оцінка якості освіти, університет, конкурентоспроможність, управління, контроль

\section{Контроль системы обеспечения качества образования в современном украинском университете}
Е. С.Александрова ${ }^{1}$, И. С. Грозный르, Н. Н. Винникова ${ }^{1}$, H. А. Чувасова ${ }^{3}$ 
1 - Киевский университет имени Бориса Гринченко, г. Киев, Украина, e-mail: olena.aleksandrova@yahoo.com; n.vinnikova@kubg.edu.ua

2 - Европейский университет, г. Киев, Украина, e-mail: grozny_igor@ukr.net

3 - Криворожский государственный педагогический университет, г. Кривой Рог, Украина, e-mail:k_chemistry@ kdpu.edu.ua

Цель. Разработка системы внутренней оценки и обеспечения качества образования в украинских университетах для повышения их конкурентоспособности в условиях глобализации и интернационализации высшего образования.

Методика. Использование системного, структурно-функционального, институционального подходов дает возможность изучить международный опыт оценки качества высшего образования и найти пути его имплементации в украинских реалиях. Применение методов анализа, синтеза, обобщения, сравнения, экспертной оценки позволяет разработать систему проведения внутреннего аудита в университетах. Использование квалиметрического подхода позволило предложить алгоритм расчета качества высшего образования в университетах на основе совокупности количественных показателей.

Результаты. Анализ международного опыта обеспечения конкурентоспособности высшего образования позволил выделить критерии, по которым оценивается качество образования, разработать алгоритм проведения внутренней оценки качества высшего образования и определить механизм его контроля в украинских университетах. Оценка качества образования в университете состоит из ана- лиза основных процессов управления, взаимодополняющих процессов и процессов совершенствования. Уровень функционирования этих процессов влияет на качество высшего образования что, в свою очередь, позволяет обосновать факторы дальнейшего повышения продуктивности работы университета в предоставлении образовательных услуг.

Научная новизна. Разработана стратегия создания системы внутреннего обеспечения качества высшего образования в украинских университетах. Ее можно воплотить через определение преимуществ и недостатков, возможностей и угроз проведения внутреннего аудита качества высшего образования, а также с помощью анализа международного опыта обеспечения конкурентоспособности высшего образования, который обобщается в соответствующих стандартах качества. Разработан алгоритм проведения оценки качества высшего образования в украинских университетах и определена специфика управления образовательной деятельностью на основе квалиметрической оценки качества (повышения полезности) предоставления образовательных услуг.

Практическая значимость. Результаты исследования могут быть использованы для реализации и/ или совершенствования механизма внутреннего аудита системы качества образования в университетах.

Ключевые слова: оценка качества образования, университет, конкурентоспособность, управление, контроль

Рекомендовано до публікації докт. екон. наук Л. М. Мельник. Дата надходження рукопису 05.01.18. 